\title{
Application of Technical and Soft Skills in the First Job Experience by Accountancy Graduates in the Philippines: Implications for Accounting Curriculum Development
}

\author{
Chester Owen B. Diokno', Williams Kwasi Peprah² \\ ${ }^{1}$ Department of Accountancy, College of Business, Adventist University of the Philippines, Silang, Cavite, Philippines \\ ${ }^{2}$ School of Business, Valley View University, Accra, Ghana \\ Email: cobdiokno@aup.edu.ph,Williams.peprah@vvu.edu.gh
}

How to cite this paper: Diokno, C. O. B., \& Peprah, W. K. (2021). Application of Technical and Soft Skills in the First Job Experience by Accountancy Graduates in the Philippines: Implications for Accounting Curriculum Development. Open Journal of Accounting, 10, 111-124.

https://doi.org/10.4236/ojacct.2021.103010

Received: June 3, 2021

Accepted: July 19, 2021

Published: July 22, 2021

Copyright $\odot 2021$ by author(s) and Scientific Research Publishing Inc. This work is licensed under the Creative Commons Attribution International License (CC BY 4.0).

http://creativecommons.org/licenses/by/4.0/

(c) (i) Open Access

\begin{abstract}
Currently, the labor workforce in the Philippines needs accountants brought about by the ASEAN integration. As such, there is a greater demand for universities to produce graduates who are ready to face the real world of business. To produce quality graduates, the technical and soft skills of the accountancy graduates must be in harmony. This study aimed to ascertain the technical and soft skills matching in relation to the first job experience of accountancy graduates. A descriptive-correlational design was utilized in this study. Stratified random sampling was utilized to get the 70-study sample. Self-constructed questionnaires were used in this study. Content validity was done by five experts. Percentages, mean, stand and regression were used in the analysis of data. The work profile revealed the following: $37.14 \%$ of accountancy graduates are working in the audit sector, $34.29 \%$ worked in General Accounting/Finance; 70\% of respondents are currently working with 1 3 years of experience, while $30 \%$ working beyond 3 years from the date of graduation; $45.71 \%$ of the respondents underwent internship at Alas Oplas \& Co. CPAs, and $58.57 \%$ of accountancy graduates who took the internship program spent at least 160 hours on their internship. Regression analysis revealed that the technical skills gained in the internship program of the accountancy graduates were significantly related to the technical skills applied during their first job experience. On the other hand, the Accountancy Program's soft skills are significantly related to the soft skills applied during their first job experience.
\end{abstract}

\section{Keywords}

Technical Skills, Soft Skills, Accountancy, First Job Experience, Accountancy 


\section{Introduction}

Every educational institution has to ensure that its graduates are marketable and ready to face to world of reality after graduation. The courses that made up a degree should be paralleled to what society is looking for. Currently, there is no study about the relationship of technical and soft skills needed in actual job in relation to first job experience of Accountancy graduates. It is imperative that there should be match between the product of the tertiary educational institution to the current demands of professionals needed for the labor workforce. As such, the technical skills and the soft skills gained by a graduate should be embodied in the totality of learning experience of a student during his collegiate years.

At present, the Philippines is preparing its pool of professionals who will take advantage of the mobility with its neighboring ASEAN countries to serve the region. On that note, the business students who are enrolled in higher educational institutions should be trained holistically for them to be at par with other bands of experts in their own field of specialization. The ASEAN Economic Community AEC has an estimated population of over 600 million and this has created a competitive market for human capital provided by Indonesia, Philippines, Malaysia, Singapore, Thailand, Brunei Darussalam, Cambodia, Lao People's Democratic Republic, Myanmar, and Vietnam (Wailerdsak, 2013). It was formed to facilitate regional economic and financial integration and cooperation and aims to establish a single market and production base, a highly competitive economic region, a region of equitable economic development, a region fully integrated to engage into the global economy. ASEAN as an economic bloc is positioned to transform the region toward free movement of goods and services (CHED Memorandum Order, 2007).

Filipino Certified Public Accountants (CPAs) are ready for the ASEAN integration. Due to the high enrolment figure of 160,622 students into Bachelor of Science in Accountancy from 2015 to 2017 as reported by the Commission on Higher Education (CHED), there is the indication that the number of graduates is anticipated to be more. The market will be for graduates who have both technical and soft skills and hence this study. According to statistics from the Commission on Higher Education, there were approximately 160,622 enrollees in Bachelor of Science in Accountancy programs in 572 schools from 2015 to 2017 (CHED). During the same time period, only 23,225 students (roughly $14 \%$ of the total enrollment) graduated. The number of students enrolled in and graduates from accounting programs is expected to rise (Cuaresma, 2016).

To meet the current demand of accountants in the Philippines, higher educational institutions in the country offers the Bachelor of Science in Accountancy program, which is inclusive of technical courses that would prepare the students to hurdle the Certified Public Accountant Licensure Examination, and the soft skills needed to make the graduate well-rounded. These skills include interpersonal skills, speaking, writing, emotional intelligence, verbal reasoning, workplace ethics, among others. 
This paper aimed to give inputs on curriculum development of Bachelor of Science in Accountancy to further hone the skills of future accountants who will shape the business world in the years to come. This development focuses on the courses relevant to the program, in relation to the technical and soft skills acquired in the University and on the internship program matched with its relevance in the first-job experience of the graduates. The specific research questions were addressed in this study.

1) What is the work profile of the Accountancy graduates in terms of the nature of the present job, years of working, nature of the first job after graduation?

2) What technical and soft skills gained from the accountancy program, internship program, and applied during the first job experience?

3) Is there a significant correlation of soft skills and technical skills on the skills applied on the first job experience of the Accountancy graduates?

4) Which of the technical skills and soft skills significantly predict the skills applied on the first job experience of the Accountancy graduates?

This research aims to contribute to knowledge by empirically letting accounting educators know that the impact of the teaching of soft skills and technical skills has on the first-time job experience of students. The study is limited in the purposive sampling technique used in selecting the university; however, the actual respondents were randomly sample.

\section{Review of Related Literature}

Due to inherent competitive world of business, the professionals trained by higher educational institutions has to keep abreast in the skills necessary to prepare them for great demands of business arena. To achieve this, the students must be equipped with the necessary technical skills relevant to their first-job experience, as well as the emotional intelligence derived from the soft skills acquired by the students on the course of their academic pursuits.

Technical skills are the knowledge and abilities desired to perform specific tasks. They are useful and often relate to mechanical, information technology, math, or science tasks (Perry \& Haluska, 2016). These skills are essential in the performance of job. This can be learned through classroom discussions and giving evaluation through quizzes, tests, and examinations that would validate the fitness of the student to the profession. Technical jargons, especially in the Accountancy profession are being discussed thoroughly so that the students will be equipped in the language of business that will be applied in the first-job experience of the graduates (CHED Memorandum Order, 2007; Wyness \& Dalton, 2018). After the rigorous training and assessment, students have to take the licensure examination that is being administered twice a year, to validate if the CPA-aspirant can cope with the demand of business enterprise (Charron \& Lowe, 2009). Included among the tasks of a CPA are the preparation and maintaining financial statements and reports; examine the statements to ensure compliance with the laws and standards and numerical accuracy; proper filing, documentation and 
tax payments; keep update date the accounts books for inspection; improve business systems for a more effectiveness and efficiency; suggest ways to increase revenues, reduce cost and maximize profit and finally deliver auditing and assurance service.

To meet the above-mentioned expectation, the student has to take the examination covering the following topics: Financial Accounting and Reporting, Advanced Financial Accounting and Reporting, Taxation, Management and Advisory Services, Auditing, and Regulatory Framework for Business Transactions (CHED Memorandum Order, 2007). To prepare the students to hurdle the CPA Licensure Examination, series of tests will be supplied by the educational institution. This will validate their readiness on the technical aspect of the job experience. Higher educational institutions have to ensure that the CPA-aspirant has necessary skills to journalize financial transactions, prepare journals, ledgers, and trial balance, reconcile accounts, generate statement of financial position, comprehensive income, and changes in equity, and computation of correct amount of tax due, and proofreading of the financial statements (Perry \& Haluska, 2016).

Employers use the term "soft skills" to refer to the more intangible and nontechnical abilities that individuals are expected to possess (Cascio, 2019). Transferable skills and professional skills are terms used to describe soft skills. These are skills that are less specialized, less rooted in particular vocations, and more aligned with a person's general disposition and personality, as the term implies. Soft skills relate to attitudes and intuitions (Martin \& Pear, 2007). As soft skills are less referable to the qualifications and more personality-driven, it is important to consider what the soft skills are and how this might show evidence before they will be fitted to the job (Griffin et al., 2017). This is especially true in graduate program recruitment, where transferable skills and potential often take precedence over professional experience. Showing soft skills equates to demonstrating great potential to succeed and advance in one's chosen career (Barak, 2017).

Soft skills are important in all situations, not just when dealing with customers and clients. But when it comes to communicating with coworkers, they are equally important (Highhouse et al., 2016). The ability to collaborate with others is referred to as soft skills. Employers value soft skills because they allow them to be more productive. Soft skills are essential for a productive and healthy workplace. After all, the workplace is an interpersonal space where relationships must be formed and nurtured, viewpoints must be exchanged, and disputes must be settled on occasion (Viviers et al., 2016).

Five years from now, over one-third of skills (35\%) that are considered important in today's workforce will have changed. By 2020, the Fourth Industrial Revolution will have brought us advanced robotics and autonomous transport, artificial intelligence and machine learning, advanced materials, biotechnology and genomics at World Economic Forum in 2016. People expect artificial intel- 
ligence machines to be on a company's board of directors by 2026, according to a survey piloted by the World Economic Forum's Global Agenda Council on the Future of Software and Society.

As such, there is great demand of professionals who possesses a characteristic that is desirable to execute the job. The character and interpersonal skills during this time will matter (Chance, 2014). The Future of Jobs, a new Forum report, examines the future of jobs, skills, and workforce strategy. Senior human resources and strategy officers from leading global employers were asked what the current shifts mean for jobs, skills, and recruitment across sectors and geographies, and it noted soft skills at the 2016 world economic forum. To address this, the students should be equipped by the soft skills acquired through the preparation in the undergraduate degree.

According to Brantley (2017) those who cannot learn, unlearn, and relearn will be the illiterates of the twenty-first century, not those who cannot read and write.

The fourth industrial revolution would disrupt many industries and eliminate many jobs, but it does not necessarily mean the end of the world. Investing in skills that will be useful in 5 or 10 years is a smart move toward securing a position in the workforce. Hard skills, it is said, can be learned, but soft skills, such as attitude, mentality, and people management skills, are the characteristics that distinguish us from a machine of codes and algorithms, and will be the most important in the future workplace (Hong, 2016).

Internships are increasingly becoming a required component of undergraduate programs. It allows students to transition smoothly from the on-campus environment to the workplace. It's often regarded as a "win-win" situation for both the intern and the intern's boss. Students should learn about the profession and get hands-on experience while also reflecting on what they've learned in class. Internships benefit employers because interns are potential future workers (Muhamad et al., 2009).

Internships appear to be beneficial to both students and employers, based on the growth of accounting internship programs and their popularity among students and employers. The American Accounting Association's (AAA) Committee on Internship Programs recognized the following advantages for students as early as 1952: 1) exposure to accounting methods and problems not found in the classroom; 2) improved business comprehension; and 3) increased ability to assess and assimilate classroom experiences Internships, according to the Committee, provide students with the chance to see if they enjoy the field of work they have chosen. If students do not enjoy their internship, they can pursue other options before committing to full-time jobs. Lowe (1965) reported that former interns felt their internships clarified certain points of accounting theory previously studied and that $66 \%$ believed that courses taken after the internship were more "meaningful" due to their real-world working experiences. Internships, according to Patacsil and Tablatin (2017), encourage students to work 
hard early in their academic programs in order to increase their chances of being given internships and to improve their grades once those internships are completed.

Students benefit from internships, according to the Accounting Education Change Commission (1990), because they gain first-hand experience applying accounting and auditing skills to real-world issues. Working with others, coordinating and delegating, resolving conflict, understanding the internal workings of an organization, and gaining an understanding of interpersonal and group dynamics in business are all skills and knowledge that the AECC identified as essential to an internship experience. Aside from the benefits to students, the sponsoring institution has a number of advantages. The school is said to benefit from the opportunity to compare the content of its academic curriculum to the real practices that its student participants have encountered (Fryling et al., 2018). The increased collaboration and communication between the school and the business entities participating in the program also benefits the school. These connections may lead to higher placement rates for future graduating students (Johnson Stage, 2018).

Finally according to Dissanayaka (2016), there are alleged benefits for employers who take part in internship programs. The most obvious benefit is that hiring companies will find highly motivated and qualified employees for a low cost. They also have the advantage of being able to preview prospective future hires before making permanent employment offers to them. Internships can also be used as marketing tools to improve a company's reputation at a specific university.

\section{Methodology}

The study used descriptive-correlational research method. Correlational research describes the relationships of variables (Peprah, 2021). This was utilized in this study to determine whether the technical and soft skills gained in the university and in the internship program is related to the first-job experience of graduates. Graduates of Bachelor of Science in Accountancy were randomly selected from a private university in the Philippines. The private university was purposively selected. The researcher secured a complete list of the total population of BSA graduates from the Department of Accountancy of College of Business. A total of 70 individuals out of 100 responded on the research material based on Cochran formula. The magnitude of the strength of the relationship is determined and interpreted on the absolute values of Cohen (1988) where $r=0.10$ to 0.29 is small/low, $r=0.30$ to 0.49 is medium/moderate, and $r=0.50$ to 1.0 is large/high.

Self-constructed questionnaires were used in this study. The instrument reliability was 0.85 for Technical Skill, 0.88 for Soft Skills. Majority of the respondents were from 2017 graduates, which comprises 19/70. Of the total 70 respondents, 45 are female and 25 are male. $71.43 \%$ of the respondents belong to age group of below 25 years old as shown in Table 1. 
Table 1. Demographic profile.

\begin{tabular}{lcc}
\hline \multicolumn{1}{c}{ Sex } & Frequency & Percent \\
\hline Male & 45 & 64.3 \\
Female & 25 & 35.7 \\
Total & 70 & 100 \\
\hline Age & & \\
\hline 26 - 50 years old & 20 & 28.6 \\
Below 25 years old & 50 & 71.4 \\
Total & 70 & 100 \\
\hline
\end{tabular}

\section{Results}

Work profile. The work profile of the respondents was determined in terms of the nature of the present work, total number of years working, and nature of first job as shown in Table 2.

Large group (37.1\%) of accountancy graduates are working on the audit sector. They are followed by those who are General Accounting/Finance. There were 26 and 24 professionals, respectively, belong to that category.

Forty nine respondents are currently working with 1 - 3 years of experience, while 28 are working beyond 3 years from the date of graduation as shown in Table 3. Furthermore Table 4 present the current result where there were 49 professionals working in the Audit Sector. As respondents underwent internship at Alas Oplas \& Co. CPAs, they represent $45.71 \%$ of the total respondents. Of all the respondents, 41 accountancy graduates who took the internship program spent at least 160 hours on their internship.

Table 5 presented that majority of the respondents agreed that the relevant technical skills needed for the first job experience were gained in the accountancy program and in the internship program.

Table 6 also showed that majority of the respondents agreed that the relevant soft skills needed for the first job experience were gained in the accountancy program and in the internship program.

Correlation of Soft Skills and Technical Skills on the Skills Applied on the First Job.

The bivariate correlation of the technical skills and soft skills learned in the Accountancy program and in the Internship Program were all correlated with the technical and soft skills applied in the first job experience of the graduates as shown in Table 7.

The regression analysis in Table 8 revealed that the technical skills gained in the internship program of the accountancy graduates were significantly related to the technical skills applied during their first job experience as presented in Table 7. The skills gained from the Accountancy program was not a significant predictor of their skills applied during the first job experience. Only $28 \%$ of the variance in the technical skills applied in their first job experience was contributed by the technical skill during their internship program. 
Table 2. Nature of the present job.

\begin{tabular}{lcc}
\hline \multicolumn{1}{c}{ Nature of the Present Job } & Frequency & Percent \\
\hline Academe & 2 & 2.9 \\
Administrative & 1 & 1.4 \\
Audit & 26 & 37.1 \\
Banking & 1 & 1.4 \\
Consulting & 1 & 1.4 \\
General Accounting & & \\
Finance & 24 & 34.3 \\
Government & 2 & 2.9 \\
Government Accounting & 1 & 1.4 \\
Management & 5 & 7.1 \\
Management Consultancy & 1 & 1.4 \\
Self-employed & 1 & 1.4 \\
Standard and Controls & 1 & 1.4 \\
NA & 2 & 2.8 \\
Total & 70 & 100 \\
\hline
\end{tabular}

Table 3. Total of years working.

\begin{tabular}{ccc}
\hline & Total number of Years Working & \\
\hline 1 - 3 years & 41 & 58.6 \\
$4-7$ years & 21 & 30 \\
Below 1 year & 8 & 11.4 \\
Total & 70 & 100 \\
\hline
\end{tabular}

Table 4. Nature of the first job after graduation.

\begin{tabular}{ccc}
\hline & Nature of First Job after Graduation & \\
\hline Academe & 1 & 1.4 \\
Administrative & 1 & 1.4 \\
Advisory & 1 & 1.4 \\
Audit & 49 & 70 \\
General Accounting/Finance & 14 & 20 \\
Government & 2 & 2.9 \\
Management & 1 & 1.4 \\
Taxation & 1 & 1.4 \\
Total & 70 & 100 \\
\hline
\end{tabular}

Table 9 showed that the soft skills gained in Accountancy Program are significantly related to the soft skills applied during their first job experience. Of the four factors (technical skills gained in Accountancy Program technical skills gained in Internship Program, soft skills learned on Internship, and soft skills gained in Accountancy Program) considered in the regression as analysis to predict 
Table 5. Technical skills gained from the accountancy program, internship program, and applied during the first job experience.

\begin{tabular}{|c|c|c|c|c|c|c|}
\hline Accountancy & & Percent $t$ & Internship & Percent $t$ & First Job & Percent $\mathrm{t}$ \\
\hline Technical Skills & Program & & Program & & $E$ & \\
\hline Journalizing financial & & 100.00 & & 52.86 & & 77.1 \\
\hline Transaction & 70 & & 37 & & 54 & 4 \\
\hline Preparing journals, & & 100.00 & & 55.71 & & 77.1 \\
\hline ledgers, and trial balance & 70 & & 39 & & 54 & 4 \\
\hline Reconciliation of & & 100.00 & & 65.71 & & 95.7 \\
\hline Accounts & 70 & & 46 & & 67 & 1 \\
\hline \multicolumn{7}{|l|}{ Generating statement of } \\
\hline \multicolumn{7}{|l|}{ financial position, } \\
\hline comprehensive income, & & 94.28 & & 42.86 & & 87.1 \\
\hline and changes in equity & 66 & & 30 & & 61 & 4 \\
\hline Computation of correct & & 98.57 & & 34.29 & & 78.5 \\
\hline amount of tax due & 69 & & 24 & & 55 & 7 \\
\hline Proofreading the & 50 & & 55 & & 63 & \\
\hline Financial statement & 71.43 & 78.57 & 90.0 & 0 & & \\
\hline
\end{tabular}

Table 6. Soft skills gained from the accountancy program, internship program, and applied during the first job experience.

\begin{tabular}{|c|c|c|c|c|c|c|}
\hline Soft Skills & $\begin{array}{c}\text { Accountancy } \\
\text { Program }\end{array}$ & Percent & $\begin{array}{l}\text { Internship } \\
\text { Program }\end{array}$ & Percent & $\begin{array}{l}\text { First Job } \\
\text { Experience }\end{array}$ & Percent \\
\hline \multicolumn{7}{|l|}{ Complex Problem Solving } \\
\hline and Critical Thinking & 70 & 100.0 & 44 & 62.86 & 67 & 95.71 \\
\hline Emotional Intelligence & 63 & 90.00 & 65 & 92.86 & 67 & 95.71 \\
\hline Creativity & 59 & 84.29 & 50 & 71.43 & 55 & 78.57 \\
\hline \multicolumn{7}{|l|}{ People Management, } \\
\hline \multicolumn{7}{|l|}{ Relationship with co- } \\
\hline $\begin{array}{l}\text { workers, and coordination } \\
\text { with others }\end{array}$ & 62 & 88.57 & 65 & 92.86 & 69 & 98.57 \\
\hline \multicolumn{7}{|l|}{ Judgment and Decision } \\
\hline Making & 68 & 97.14 & 55 & 78.57 & 69 & 98.57 \\
\hline $\begin{array}{l}\text { Service Orientation } \\
\text { Communication skills }\end{array}$ & 67 & 95.71 & 53 & 75.71 & 67 & 95.71 \\
\hline \multicolumn{7}{|l|}{ (public speaking, oral and } \\
\hline written communication) & 65 & 92.85 & 56 & 80.00 & 66 & 94.28 \\
\hline
\end{tabular}

the soft skills applied during the first job experience, only soft skills gained in Accountancy Program is significant. The total variance accounted for in the dependent variable is $21 \%$. The other percentage is contributed by other factors that were not included in the study. 
Table 7. Correlation of soft skills and technical skills on the skills applied on the first job.

\begin{tabular}{|c|c|c|c|c|c|c|c|c|}
\hline \multicolumn{9}{|c|}{ First Job Experience } \\
\hline & \multicolumn{4}{|c|}{ Technical Skill } & \multicolumn{4}{|c|}{ Soft Skills } \\
\hline Skills & $\mathrm{r}$ & $\mathrm{p}$-value & VI & $\begin{array}{c}\text { Magnitude of } \\
\text { Effect Size }\end{array}$ & $\mathrm{r}$ & $\mathrm{p}$-value & VI & $\begin{array}{c}\text { Magnitude of } \\
\text { Effect Size }\end{array}$ \\
\hline Technical-Accountancy & $0.252^{\star}$ & 0.036 & S & Low & $0.339^{* *}$ & 0.000 & $\mathrm{~S}$ & Medium \\
\hline Technical-Internship & $0.529^{\star *}$ & 0.000 & S & High & $0.239^{*}$ & 0.046 & S & Low \\
\hline Soft skills-Accountancy & $0.406^{* *}$ & 0.000 & S & Medium & $0.458^{\star *}$ & 0.000 & $\mathrm{~S}$ & Medium \\
\hline Soft Skills-Internship & $0.464^{\star *}$ & 0.000 & $\mathrm{~S}$ & Medium & $0.373^{\star *}$ & 0.001 & $\mathrm{~S}$ & Medium \\
\hline
\end{tabular}

$\mathrm{VI}=$ Verbal Interpretation. $\mathrm{S}=$ Significant. ${ }^{* *}$ sig at $0.01,{ }^{*}$ sig at 0.05 .

Table 8. Skills that predict technical skills applied during the first job experience.

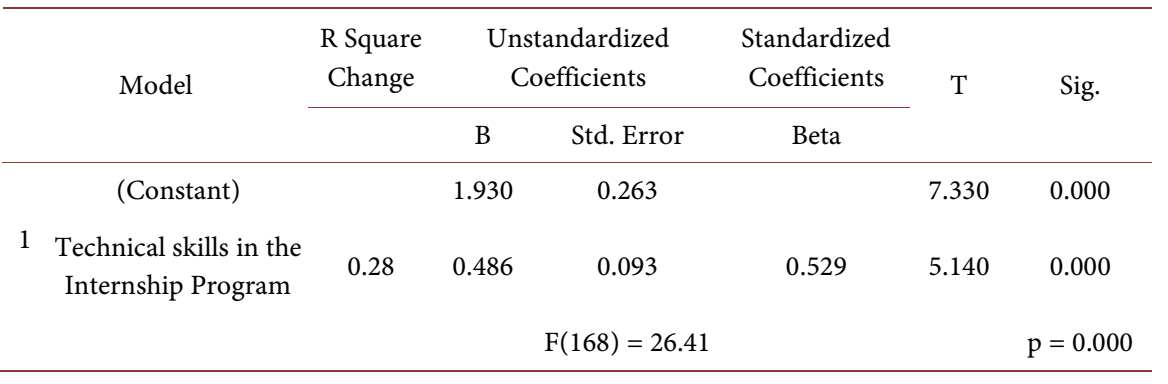

Table 9. Skills that predict soft skills applied during the first job experience.

\begin{tabular}{|c|c|c|c|c|c|c|c|}
\hline & \multirow[t]{2}{*}{ Model } & \multirow[t]{2}{*}{$\begin{array}{l}\text { R Square } \\
\text { Change }\end{array}$} & \multicolumn{2}{|c|}{$\begin{array}{l}\text { Unstandardized } \\
\text { Coefficients }\end{array}$} & \multirow{2}{*}{$\begin{array}{c}\begin{array}{c}\text { Standardized } \\
\text { Coefficients }\end{array} \\
\text { Beta }\end{array}$} & \multirow[t]{2}{*}{$\mathrm{T}$} & \multirow[t]{2}{*}{ Sig. } \\
\hline & & & B & Std. Error & & & \\
\hline \multirow{3}{*}{1} & (Constant) & & 1.730 & 0.421 & & 4.100 & 0.000 \\
\hline & $\begin{array}{c}\text { Soft Skills in the } \\
\text { Accountancy Program }\end{array}$ & 0.21 & 0.541 & 0.127 & 0.458 & 4.250 & 0.000 \\
\hline & & & \multicolumn{2}{|r|}{$F(168)=18.05$} & & \multicolumn{2}{|r|}{$\mathrm{p}=0.000$} \\
\hline
\end{tabular}

\section{Discussion}

This paper was formed to contribute valuable inputs on curriculum development of Bachelor of Science in Accountancy. It is said that the outcome-based learning experience will define the success of a collegiate program. This will matter if the graduate of a certain program positioned himself to his chosen profession with the aid of the educational institution which he attended (Perry \& Haluska, 2016). The courses within the program must embody the demands of the future job. As such, the technical and soft skills of a student must be in harmony. These courses which is geared toward technicalities of the accounting profession, as well as the courses aimed to hone the interpersonal skills of a student must be developed. This curriculum development focuses on the courses relevant to the program, in relation to the technical and soft skills acquired in the University and on the internship program matched with its relevance in the first-job experience of the graduates. 
Out of 70 Accountancy graduates responded, $37.1 \%$ of them are working on the audit sector. They are followed by those who are General Accounting/Finance. There were 26 and 24 professionals, respectively, belong to that category. Forty nine respondents are currently working with 1 - 3 years of experience, while 28 are working beyond 3 years from the date of graduation. Currently, there were 49 professionals working in the Audit Sector. 32 respondents underwent internship at Alas Oplas \& Co. CPAs. They represent $45.71 \%$ of the total respondents. Of all the respondents, 41 accountancy graduates who took the internship program spent at least 160 hours on their internship.

While there are ample opportunities for both experienced and entry-level workers in finance and accounting, the field is constantly evolving. However, the technicalities of being an accountant should not be compromised (Cuaresma, 2016). Based on the study gathered, the following essential accounting technical knowledge were applied on the first job experience of a graduate: 1) Journalizing financial transactions; 2) Preparing journals, ledgers, and trial balance; 3) Reconciliation of accounts (bank reconciliation, aging schedule, lapsing schedule); 4) Generating statement of financial position, comprehensive income, and changes in equity; 5) Computation of correct amount of tax due; and 6) Proofreading the financial statements (i.e. footing, cross footing, referencing). These skills were taught extensively during the four and half years of training within the Accountancy program. As evidenced by the responses of the 70 Accountancy graduates, they attested that the Accountancy program had prepared them extensively, and it was thoroughly applied in their first job experience as a professional. This means that the technical skills acquired in the accountancy program is sufficient and is matched with the current demands of business profession in the world of accounting.

Essential job skills for accounting professionals encompass more than the ability to crunch numbers, complete expense sheets and depreciate fixed assets. Aside from traditional accounting knowledge, there are a handful of other soft skills that every accounting professional needs (Herbert et al., 2017). The roles of accounting and finance professionals are expanding. Given the frequent interaction with other departments, today's accounting professionals need sound decision-making, negotiation and strategic-thinking skills. It's also important to be able to see the big picture and understand how your accounting role impacts the overall organization (Chance, 2014).

The result of the survey presented that the accountancy graduates acquired the necessary interpersonal skills that they need in their job. The following soft skills are acquired in the accountancy program, which were applied in the first job experience of a graduate: 1) complex problem solving and critical thinking; 2) emotional intelligence; 3) creativity; 4) people management, relationship with co-workers, and coordination with others; 5) judgment and decision making; 6) service orientation; and 7) communication skills (public speaking, oral and written communication). These soft skills are in congruence with the current demands of the Industrial Revolution. It is said that in the future, where machines 
seem to be taking the place of humans, "human skills" become increasingly important. These are the skills that would take years to be replicated by machines if it becomes possible down the road (Griffin et al., 2017).

Creative problem solving tops the list of most essential skills in 2020 (Cascio, 2019). The ability to look at problems from different perspectives and come up with effective solutions is a valuable skill to have, given the increasing number of technological innovations that could crop up in the next few decades.

As an accounting professional, communication is very vital. Accountants collaborate with a wide array of colleagues or clients. Accounting professionals need to be ambitious self-starters who can develop new insights, manage projects, and motivate and engage team members, all the while displaying solid leadership skills (Griffin et al., 2017). Accounting professionals can demonstrate good customer service by truly listening to the needs and concerns of your clients, whether they are internal or external. A positive attitude can also go a long way, especially when stress levels are high (Cascio, 2019). This means that interpersonal skills developed while the student is in the university is relevant in the first-job experience of an accountancy graduate.

As such, it was presented that the accountancy graduates embodied the demands of their first-job experience in relation to the technical and soft skills acquired in the accountancy and internship program. It is important to note that the current courses being taught in the accountancy curriculum is matched in the current demands of business world that the accountancy graduates is taking prior to their graduation.

\section{Conclusion}

The study revealed that there is a positive significant relationship in the technical and soft skills gained in the internship program of the accountancy graduates in relation to the technical and soft skills applied during their first job experience of the accountancy graduates.

There is strong relationship that exists in accountancy program, internship and the first job experience of a graduate to the required technical and soft skills. We need to ensure that graduates are equipped to deal with the demands of a complex global business environment through the harmonious matching of technical and soft skills of a graduate, to ascertain their readiness in the business world.

\section{Recommendation}

The following are the recommendation of the study:

1) Maintain, and/or further improve the learning experience of Accountancy students for them to be ready for the real world of business after graduation.

2) Increase the number of required hours in the internship program for Accountancy students.

3) Revisit the Accountancy curriculum to include more courses that are relevant in exposing students to practical approaches of business, and to further develop 
their interpersonal skills.

4) Through a collaborative effort, accountancy departments can further improve the curriculum to meet the future work demand and enhance the work readiness of the students. Accountancy departments should encourage and invite recruiters and potential employers to hold workshops and presentations on campus to convey the expectations of general employment and required skill sets to students.

5) In addition, accountancy department and the faculty should disseminate employer expectations to students. Employers and accountancy departments should set up an effective mentoring program to guide students to develop further the technical and soft skills of the students.

\section{Conflicts of Interest}

The authors declare no conflicts of interest regarding the publication of this paper.

\section{References}

Accounting Education Change Commission (1990). Objectives of Education for Accountants: Position Statement Number One. Issues in Accounting Education, No. 5, 307-312.

Barak, M. (2017). Managing Diversity toward a Globally Inclusive Workplace (4th ed.). London: SAGE Publications Ltd.

Brantley, J. A. (2017). Development of a Twenty-First Century Skills Inventory. Doctoral Dissertation, Mobile, AL: University of South Alabama.

Cascio, W. F. (2019). Managing Human Resources: Productivity, Quality of Work Life, Profits (11th ed., pp. 340-345). New York: McGraw Hill Education.

Chance, P. (2014). Learning and Behavior (7th ed.). Belmont, CA: Cengage Learning.

Charron, K., \& Lowe, D. J. (2009). Becoming a CPA: Evidence from Recent Graduates. The Accounting Educators' Journal, 19, 11-20.

CHED Memorandum Order No. 3 Series 2007, Revised Policies and Standards for Bachelor of Science in Accountancy (BSA), as Amended. http://www.prc.gov.ph

Cohen, J. W. (1988). Statistical Power Analysis for the Behavioral Sciences (2nd ed.). Hillsdale, NJ: Lawrence Erlbaum Associates.

Cuaresma, J. (2016). Filipino CPAs' Readiness to "Level Up" to Asean, World Standards. The Manila Times, 3.

Dissanayaka, D. M. G. L. (2016). How They Perceive Their Internship Programme: An Empirical Analysis on Undergraduates of B.Sc. Accounting (Special) Degree Programme of. Doctoral Dissertation, Nugegoda: Department of Accounting, University of Sri Jayewardenepura.

Fryling, M., Egan, M., Flatland, R. Y., Vandenberg, S., \& Small, S. (2018). Catch'em Early: Internship and Assistantship CS Mentoring Programs for Underclassmen. Proceedings of the 49th ACM Technical Symposium on Computer Science Education, Baltimore, 21-24 February 2018, 658-663. https://doi.org/10.1145/3159450.3159556

Griffin, R., Phillips, J., \& Gully, S. (2017). Organizational Behavior: Managing People and Organizations (pp. 551-557). Boston, MA: Cengage Learning.

Herbert, W. E., Tsegba, I. N., Ene, E. E., \& Onyilo, F. (2017). The Rise of Fraud Examina- 
tion and Forensic Accounting in Africa: The Nigerian Experience. Archives of Business Research, 5, 1-18. https://doi.org/10.14738/abr.54.3013

Highhouse, S., Doverspike, D., \& Guion, R. (2016). Essentials of Personnel Assessment and Selection (2nd ed.). New York: Taylor and Francis Group. https://doi.org/10.4324/9781315690667

Hong, R. (2016). Soft Skills and Hard Numbers: Gender Discourse in Human Resources. Big Data \& Society, 3. https://doi.org/10.1177/2053951716674237

Johnson, S. R., \& Stage, F. K. (2018). Academic Engagement and Student Success: Do High-Impact Practices Mean Higher Graduation Rates? The Journal of Higher Education, 89, 753-781. https://doi.org/10.1080/00221546.2018.1441107

Lowe, R. (1965). Public Accounting Internships. The Accounting Review, 40, 839-846.

Martin, G., \& Pear, J. (2007). Behavior Modification: What Is and How to Do It (8th ed.). Upper Saddle River, NJ: Pearson Education, Inc.

Muhamad, R., Yahya, Y., Shahimi, S., \& Mahzan, N. (2009). Undergraduate Internship Attachment in Accounting: The Interns Perspective. International Education Studies, 2, 49-55. https://doi.org/10.5539/ies.v2n4p49

Patacsil, F. F., \& Tablatin, C. L. S. (2017). Exploring the Importance of Soft and Hard Skills as Perceived by IT Internship Students and Industry: A Gap Analysis. Journal of Technology and Science Education, 7, 347-368. https://doi.org/10.3926/jotse.271

Peprah, W. K. (2021). Research Methodology. https://www.researchgate.net/publication/352644604_RESEARCH_METHODOLOGY

Perry, D., \& Haluska, M. (2016). Hiring Greatness: How to Recruit Your Dream Team. Hoboken, NJ: John Wiley \& Sons, Inc. https://doi.org/10.1002/9781119176619

Viviers, H. A., Fouché, J. P., \& Reitsma, G. M. (2016). Developing Soft Skills (Also Known as Pervasive Skills): Usefulness of an Educational Game. Meditari Accountancy Research, 24, 368-389. https://doi.org/10.1108/MEDAR-07-2015-0045

Wailerdsak, N. (2013). Impacts of the ASEAN (Association of South East Asian Nations) Economic Community on Labour Market and Human Resource Management in Thailand. South East Asia Journal of Contemporary Business, Economics and Law, 2, 1-10.

Wyness, L., \& Dalton, F. (2018). The Value of Problem-Based Learning in Learning for Sustainability: Undergraduate Accounting Student Perspectives. Journal of Accounting Education, 45, 1-19. https://doi.org/10.1016/j.jaccedu.2018.09.001 